\title{
The Emergence of Brand Building: William Lever and Sunlight Soap (UK, 1884)
}

\begin{abstract}
The patent and copyright laws of the late nineteenth century, in Europe and the US, made possible the protection of intellectual and financial capital invested in brands and trademarks. Within this legal context the 'Napoleon of Soap,' William Hesketh Lever, brought to market one of the first brands of the modern era. The success of Sunlight Soap was based on product and packaging innovation and a series of marketing activities. Modern brand theory gives us a means of interpreting these activities. We find that while there was no apparent theoretical structure, Lever nevertheless created a template for brand building.

Beginning with Sunlight Soap the brand, and Port Sunlight the factory and workers village, the association with corporate philanthropy has become a consistent feature of the parent corporation. In 2013 Unilever launched Project Sunlight, a new initiative to motivate millions of people to adopt more sustainable lifestyles.
\end{abstract}

\section{Keywords:}

Sunlight Soap, brand history, brand associations, customer based brand equity, William Lever. 
Brands have become some of the most valuable assets of businesses in the global marketplace. Their role in creating value (both financial and social) has been widely recognised and has been the subject of extensive research from a legal and economic standpoint (Wilkins, 1991; da Silva Lopes, 2003; Duguid 2003; da Silva Lopes and Casson, 2007). Brands have become a stabilising force in the economy because they consolidate demand for specific products. They are thus valuable to brand owners and consumers. The conditions for the success of brands have been made possible by key events in business history, most notably the introduction of trade mark and patent laws in Europe and the US at the end of the nineteenth century: As Lury (2008) noted, "trade mark law is a significant actor in the organisation of producer markets, operating so as to consolidate and legitimate the use of branding as a...mode of capital accumulation" (Lury, 2008:201). In other words, brands first gain protection within the new legal framework and then flourish as the means of facilitating the marketplace exchanges between producers and consumers. In this paper we extend the legal and economic account of brands by incorporating the perspective of marketing theory in order to demonstrate how brand equity develops over time. We concur with the assertion of Mercer (2010) and Church and Clark (2001) that development of branding is a neglected theme in business history. Hence, in this paper we aim to connect the two bodies of literature -Marketing Theory and Business History to analyse the development of Sunlight Soap brand.

Existing studies (Fullerton, 1988; Strasser, 1995; Church, 1999) have explored business history focussing on means of production and consumption but in the process, have overlooked how brands facilitate connections between these two domains. We argue that branding is a relational concept that elevates raw material and production goods from the level of commodity to something that embodies other forms of value (such as social capital). 
In this paper we demonstrate how Lever in mid 1880s initiated different practices underpinning contemporary brand equity. It is important to note that systematic studies on branding emerged much later, in 1980s, yet Lever's dramatic creation of the business of Sunlight Soap, gives evidence of the beginning of product and corporate branding in the UK. The brand is described as "an intangible asset with long-term and complex network effects" (Saiz and Castro, 2015). The potential longevity of brands is clearly demonstrated by the contemporary global dominance of brands like Coca Cola, born in 1886, and McDonald's, 1955. The longevity of these brands underpin longevity of the parent firms. Other brands that began in the nineteenth century and whose success underpinned their modern companies (even when the ownership structure had changed) includes: Anchor butter, Cadbury, Clarks shoes, Hovis bread, Twinings, (Baren 1992). However, what is missing is a historical context of the activities of branding which underpins these successful and enduring brands.

The existing literature on brands within the context of business history has thus far looked at brands and trademarks in their "economic, social, cultural and historical context." (da Silva Lopes and Duguid, 2010). In this study we will add a new perspective to this ongoing discussion. Beginning in the 1990's marketing theorists began to develop models to analyse the sources of brand strength. Armed with insights from contemporary marketing theory our research critically deconstructs how the Sunlight brand was built, with a focus on various dimensions of brand equity. We argue that even though the economic value of the brand Sunlight has declined over time, the distinctive attributes that Lever attached to the brand have survived as part of the corporate identity of the Unilever organisation, and thus provide an enduring value to the company beyond the contribution of the particular consumer branded product. In the process we attempt to 'normalise and contextualise' Lever who is elsewhere either feted or demonised in business history literature (Lewis, 2014). 
The network of effects associated with the power of the original brands is complex. In some cases the brand (for example, Cadbury) is now owned by another company (Mondelez International). But in many cases specific brands have underpinned the success and longevity of their parent firm. The complex network of effects created by a successful brand can be seen in this research to include their effects on corporate strategy. Thus, it is imperative that we pay attention to how these brands originated (both practically and conceptually); what attributes were associated with them; and how, in the example of Sunlight, the same values which drove the original success can also be used to underpin the Sustainability initiative called Project Sunlight ${ }^{1}$.

We aim to highlight the long-term effects of a brand on the wider strategic objectives of the organisation, even though the brand itself many not be considered central to the company's continued growth ${ }^{2}$. Our research concurs with findings of da Silva Lopes and Duguid (2010) who also demonstrated the longevity of brands, albeit with a difference. We note that the relevance of Sunlight is found in the brand associations which were among the original sources of its strength as a brand. In this context, Lever's decision to name the model village and factory Port Sunlight, establishes a point of origin, both geographically and conceptually, for anchoring the brand, Sunlight Soap, and the company, Lever Brothers. We also argue that many of the concepts in current branding theory (Aaker 1991) were anticipated and embedded in the development of branding of Sunlight Soap from 1884 onwards, and that the evolution from a brand to a corporate initiative is underpinned by those original brand associations (Ignatius, 2012).

\footnotetext{
${ }^{1}$ https://www.unilever.co.uk/news/press-releases/2013/unilever-launches-projectsunlight.html

${ }^{2}$ Unilever markets Sunlight soap, as a laundry soap, in a handful of countries, particularly in South Asia and Africa.
} 
The field of business history has been invigorated recently by a series of critical reflections on the methodological approaches that are appropriate for advancing knowledge in this domain. (Clark and Rowlinson, 2004) The deterministic version of history which has dominated organizational history has been challenged by the postmodern turn in social sciences and humanities. As a result, the business history field is adopting interpretative approaches which go beyond seeing the past as a chronology of the firm's events, but as a reservoir of meanings. Keiser (1994:611) argues for the importance of history in organization studies to 'teach us to interpret existing organizational structures not as determined by laws, but as the result of decisions in past choice opportunities'. In the example of Sunlight we show that the historical decision to associate the brand with an innovative example of enlightened capitalism (the values of Port Sunlight) has created an opportunity for the modern corporation. Unilever today has organized its business operations to take advantage of the brand associations which were added to the historical brand. The great advantage of brand associations is that they belong both to the company and to consumers. Because of the embedded associations which were created as a result of decisions made by Lever at the beginning of the firm's life, current managers have the option to make use of the past according to the needs of the organisation.

Although much has been written about William Lever and the Port Sunlight factory, this is the first study to focus on the development of the Sunlight Soap brand. It combines archival research with contemporary branding theory and promotes the dialogue between business history and modern marketing management practices. As such, it belongs to the "historical studies within management" identified by Decker et al. (2015:32).

Unilever opened their archives and gave unprecedented access to the Cambridge University historian Charles Wilson when he wrote the 2 volume History of Unilever in 1954. (He added a third volume in 1968 covering the period 1945-65). Wilson studied the archival 
material and met with all of the principal actors including Lord Leverhulme. Some scholars (Wilson and Toms, 2008) consider that Charles Wilson's History of Unilever was one of the earliest and most influential company histories. All subsequent students of Unilever are indebted to Wilson and in this study we make use of his work, particularly Volume 1 which concentrates on Lever from 1860 to 1929. Whereas work of Wilson (1954) and Jones (2005) focused on the growth and transformation of Unilever, the multinational corporation, through the lens of strategy and structure, other scholars have produced biographical accounts of Lever and implications of his businesses on various domains (see for instance: Williams, 1948; Jolly, 1976; Knox, 1976; Hutchinson, 2003; Lewis, 2008; Macqueen, 2011) . However, the focus of these works was not on the branding of Unilever products and as a result they have missed Lever's attempts to engage in branding Sunlight Soap (product branding) and Lever Brothers (corporate branding). The simultaneous branding of the product and the corporate entity provides us insights into his efforts in the context of his time.

We agree with Church (1999) who saw the history of marketing as a field which occupies the hinterland between the study of firms and production on the one side and consumers and patterns of consumption on the other. Church (1999:401) writes: 'the introduction, diffusion, and development of identifiably modern techniques of marketing occurred at different times and at different speeds, depending upon the characteristics of the economy, industry, or product market under consideration.' Our example of Sunlight soap shows an instance of how a brand within a rapidly expanding product category applied branding techniques that ruptured existing markets and created new forms of product identity and consumer loyalty. Our research supports Church's argument that the history of marketing by British companies (including Lever Brothers and subsequently Unilever) challenges the production-driven interpretation of business development in contemporary business history. Church's (2008) analysis of the role of the salesman in the nineteenth and early twentieth centuries brings into 
focus a more balanced understanding of how producers developed an array of marketing techniques. Lever gave sustained thought to the best techniques for salesmen and selling, advertising, packaging, and promotions. Lever learned from visits to the US and by hiring Sydney Gross to run his London business ${ }^{3}$.

The paper is structured as follows: First we set out the context, objectives and method of the study. Following this we explain the current dominant approaches within marketing theory regarding brands and brand equity. In order to demonstrate the way in which Sunlight Soap exemplifies the concerns of current branding theory it is necessary to explain the main models of branding. Marketing management scholars and practitioners are agreed on the importance and benefits of branding, even while they may disagree on the relative merits of the different approaches to unpacking all of the dimensions of what it means to be a strong brand (Aaker, 1991; Kornberg, 2010; Christodoulides and de Chernatony, 2010; Keller, 2012;). In the subsequent section, we focus on Sunlight Soap. Here we highlight the underlying arguments Lever made in creating and building the brand Sunlight. Implicit in his actions, we argue, there is a logic of brand and corporate identity creation. That logic is validated by modern marketing theory. We demonstrate this hypothesis by using a model of brand architecture from the contemporary brand theorist, David Aaker, to examine the business decisions which were faced by Lever. In the following section, we review the contemporary literature on branding in order to make the critical connection between the birth of trademark and activities underpinning creation of branding.

\footnotetext{
${ }^{3}$ Sydney Gross joined Board of Lever Brothers after they acquired Benjamin Brooke and Co. in 1899, the owners of the Monkey Brand. This was amongst the first brand acquisitions Lever made.
} 
Wilkins (1991) argues that it is trademarks and not patents which create the conditions for the coming of age of the modern managerial corporation. She notes, "it was the trademark, as a transmitter of information that made possible the effective utilisation of patents and new technology." (Wilkins, 1991:87) Protected by the courts, trademarks, brand names and company names became essential intangible assets at the end of the nineteenth century. The registered brand name stands in place of the original manufacturer in the new era of mass production and consumption. Mercer (2010) traces the impact of the major UK trademark legislation of $1862,1875,1883,1888$, and 1905 on the consequences for brand names. In the nineteenth century product names commonly consisted of the owner's surname (or a locale or inventor of the product) coupled with a descriptive phrase: 'Glenfield Starch, Bird's Custard, Lea and Perrins's Worcestershire Sauce.' However, neither the owner's name nor the location based names were granted exclusive use when challenged by a series of legal cases. For example the term Worcestershire Sauce was open to use by anyone. When the 1883 Act created a new category of words that could be registered, namely 'fancy words not in common use' (Mercer, 2010) ${ }^{4}$ many firms set about inventing brands which were distinct from their company name or existing product line. In a letter from $1922^{5}$ Lever recalls that he selected "Sunlight" from a list of words suggested to him by a Liverpool patent agent firm, W.P. Thomson in 1884. He also registered the phrase 'The Self Washer' about the same time. Although Sunlight is clearly not a 'fancy word' the application of the word to soap was obviously deemed novel and fanciful enough to be granted trademark protection. The registration of the brand name took place just before the Board of Trade issued new instructions on 7 July 1885 "to implement a far stricter interpretation of the term 'fancy

\footnotetext{
${ }^{4}$ Mercer (2010) citing Patents, Designs, and Trade Mark's Act (1883), clause 64.

${ }^{5}$ UARM LBC 149-47.
} 
words' (Mercer, 2010:23). This stricter interpretation eventually excluded any dictionary word or geographical location.

A trademark is a form of intellectual property; it could be a name, a sign or symbol (or some combination) which is used by a manufacturer to identify his goods and distinguish them from other products or services (Levy and Rook, 1999). Brands, in contrast, include trademarks but "a brand name is more than a label employed to differentiate among the manufacturers of a product. It is a complex symbol that represents a variety of ideas and attributes. It tells the consumers many things...via the body of associations it has built up and acquired as a public object over a period of time.” (Levy and Gardner, 1955: 134). William Lever was one of the first British manufacturers who understood and expertly used the nuances of branding. With the introduction of word-only trademarks in 1883 the importance of unique symbols and visual characteristics (which were the basis of the earlier 1875 Trade Marks Act) was displaced. Owners of the branded goods now had new opportunities to build awareness for their products based on language and the symbolism of words.

During the initial years (1890 -1930), the transition from trademarks to brands was partially facilitated by means of advertising agencies. Schwarzkopf shows that the agencies (such as N. W. Ayer and J. Walter Thompson) took on the task of building up the total value (equity) of a brand in the minds of consumers. "And that consumers see brands holistically as promises of quality and individual fulfilment, was first developed tacitly in daily agency practice and only later conceptualized," (Schwartzkopf, 2013:168). This later conceptual development of the brand as a set of assets occurs in the work of $20^{\text {th }}$ century marketing theorists. Sydney Levy was one of the first marketing theorist (in the 1950s) to understand that brands had evolved to occupy a prominent role in the social lives of consumers. 
Scholars (see for example - Fullerton, 1988; Tedlow, 1990; Marchand, 1985; Strasser, 1995)

who have explored the evolution of marketing practices, consider that focused marketing and advertising activities emerged during the period between 1880 and 1920 . They associate this period as one which witnessed the emergence of a national market, which in turn created the necessary conditions for integrated marketing and advertising activities ${ }^{6}$.

Advertising was primarily concerned with attaching an image to a product and generating awareness amongst the consumers. However, advertising represents only one of the various components of marketing activities. Other components such as the development of distribution channels, the use of salesmen to call on retailers and consumers, sales promotions, point-of-sale displays, outdoor signage, public relations and pricing have all been either marginalised or neglected. Indeed, the prominence of advertising over other marketing activities has a long history and is reflected in the term 'above the line' as compared to

\footnotetext{
${ }^{6}$ The key focus of the work of Marchand, 1985; Fullerton, 1988; and Pope, 1991 is on the development of marketing institutions and role of advertising in shaping behaviour of American consumer since 1880s. Fullerton (1988) argues that marketing activities started to take root during this period and were geared towards making products available across regional boundaries. Pope (1991) in contrast finds evidence of the emergence of advertising institutions in 1890s. Strasser (1995) in her work focused on the changing consumption habits of American consumers, particularly following the second industrial revolution from 1870s onwards and the beginning of the mass market of consumer goods.. She concurs with Pope's (1991) assertion that the role of advertising changed from informing to persuading consumers. Tedlow (1991) suggests that marketing in the US evolved through three phases. Firstly, the period prior to 1880 , characterised by a fragmented market populated with small producers selling low volume and high margin goods. Secondly, advancements in communication, infrastructure and technology towards the end of nineteenth century created conditions for firms in many industries to treat national market as a single market. As a consequence, larger firms exploited economics of scale and sold undifferentiated products in high volumes at low margin. Nevertheless, Tedlow, unlike other scholars observed the emergence of market segmentation based on demographic and lifestyle considerations, which has been overlooked by Strasser. In contrast to the US, in Victorian Britain, Thomas Richards (1991), observes that by the 1890 s, advertising had started to permeate to the working class, who as a result of increasing wages and drop in prices of commodities, have emerged as the mass market.
} 
activities such as sales promotion and public relations as 'below the line' (Baker and Hart, 1987).

Branding, on the other hand is about establishing a relationship between consumers and producers. Aaker defines brand equity as, "a set of assets and liabilities linked to a brand, its name and symbol, which add to or subtract from the value provided by a product or service" (Aaker, 1991:15). Brand Equity was thus conceptualised by David Aaker as a means of capturing the consumer aspect of brand strength in addition to the financial measures of brand value. The particulars of this relationship include many components such as: brand awareness, brand liking, loyalty and perceived quality. Taken together these elements have a sort of multiplicative effect whereby they generate more brand equity together than they would as individual components. The terms brand and brand equity are often used interchangeably in the literature.

Brand accounting began in the 1980's and was focussed on food manufacturing and drinks firms. Perhaps the most significant moment was when Nestle and Jacobs Suchard fought for the control of Rowntree in 1988. Its shares were traded at $477 \mathrm{p}$ before the bid, compared with the final winning bid from Nestle at $1047 \mathrm{p}$ per share. The reason for this staggering valuation was that "Rowntree owned valuable brands such as Kit-Kat, Quality Street, Polo, After Eight and Yorkie" (Smith, 1992:117) ${ }^{7}$. Both in the UK and on Wall Street Mergers and Acquisition specialists of the 1980's gave a new prominence to brands as the vehicles of business success and M\&A traders saw themselves as unlocking the value hidden in these assets (others have called this practice "asset striping"). As a result, $83 \%$ of the price paid by Nestle for Rowntree was accounted for as 'Goodwill.' In order to make these deals, various

\footnotetext{
${ }^{7}$ With regard to Kit Kat, Rowntree registered the name as a trademark in 1911, however he did not create the brand of chocolate until 1935. This highlights the subtle difference between trademarks and brands.( http://www.nestle.co.uk/aboutus/history/nestle-uk-archives assessed on 09.02 .2017 )
} 
methods of brand valuation were proposed, most notably by the new company Interbrand, which determined the brand values for the Rank, Hovis, McDougal Group; these brand values listed as intangible assets for the Group and added to the balance sheet in the UK for the first time in 1989. The spotlight was now fixed firmly on how brands had become a major source of corporate value. Unlocking the equity, which had accumulated in consumer brands became the most important reason for corporate mergers and leveraged buyouts that characterised the 1980's. For example, in 1985 Philip Morris paid \$5.6 billion for General Foods. Three years later, the cigarette giant acquired the assets of Kraft for nearly $\$ 13$ billion, six times book value. "In each case, the purchase price reflected far more than the factories or the physical product produced therein. These corporate mergers were also about the acquisition of intangible assets--namely, brands”. (Cobb-Walgren, 1995). Similarly, Holbrook (1992) in his study of consumer electronics products found that the price premium achieved by brands exceeds what would be expected from products of similar quality, "as defined by its configuration of brand attributes, product features or physical characteristics." (1992:72).

Marketing theory had not paid particular attention to brands before that point. Even though Levy wrote his ground-breaking article 'The Product and the Brand' in 1955, the theoretical question of 'what is a brand?' did not receive systematic treatment in the marketing literature until the decade of the 1990's. The theoretical developments underpinning brands have been driven by the need to explain what sort of thing a brand is and analyse its sources of value. In the first place there is the familiar list of the things which make up a brand: name (Nike), symbol ('swoosh'), slogan ('Just Do It'). Other attributes of a brand could include: font or typeface, trademark, colour, smell, sound. However, names are the main identifier of a brand. Their importance cannot be overstated. They are the basis for awareness and communication efforts. The choice of a brand name has many implications for the future marketing of a 
product and has become the most crucial task for the creation of a new brand. In their study on marketing positioning Ries and Trout claim: "Shakespeare was wrong. A rose by any other name would not smell as sweet.... which is why the single most important decision in the marketing of perfume is the name." (Ries and Trout, 1972) The identity created by a name is an intangible asset which nonetheless has tangible value and if managed successfully has longevity that guarantees future revenue.

Interbrand, the leading UK brand valuation company, uses a valuation methodology which has three components: an analysis of the financial performance of the branded products or services, of the role the brand plays in purchase decisions, and the brand's competitive strength. Weighting together these three components allows Interbrand to propose a value for the brand. Since 1988 they have produced a ranking of the world's most valuable brands. ${ }^{8}$ The strength of their approach is that it sees brands from within the competitive marketplace context, and also takes account of the role of the brand within consumer purchase decisions.

Marketing theorists lagged the marketplace and it was not until the 1990's that marketing theorists began to offer conceptual frameworks which aimed at a theory of brand equity. Financial brand value can be calculated and argued over, however, the value that the brand has for consumers is more complex: it combines a range of behavioural (quantifiable) and attitudinal (harder to quantify) variables. The marketing term brand equity tries to capture this range of components which contribute to consumer based brand equity. There appeared to be three emergent understandings of brand equity (Cobb-Walgren et al., 1995: 26-27): 'attitudinal' (brand equity as perceptions and, possibly, intentions about brands), 'behavioural' (brand equity as responses to and actions towards brands), and 'financial'

\footnotetext{
${ }^{8}$ (http://interbrand.com/best-brands/best-global-brands/2015/ ).
} 
(brand equity as an intangible asset in a firm's balance sheet). Christodoulides and Chernatony (2010) summarised many of the competing definitions of brand equity from a marketing perspective. They note that the majority of conceptual studies agree that awareness and associations are important components of consumer based brand equity (CBBE). For example works by Kapferer (1992), Keller (1993) and Sharp (1995) introduced concepts like brand personality, brand vision and purpose and customer relationships.

Aaker showed that a combination of factors could be used to explain the sources of strength for a given brand. Interestingly, to answer the question "What is Brand Equity?" Aaker begins his 1991 work with an account of the Ivory Story. In 1882 Harley Proctor of P\&G ran the first ad for Ivory in a religious weekly stating that the soap "floated" and was "99 44/100\% pure.” Aaker (1991:4) also writes: “Curiously, in 1885 a yellow soap named Sunlight, when introduced to dreary, sun-starved England, became the start of Unilever.” Aaker's neglect of Sunlight as a brand example (in favour of Ivory) also shows a gap in the historical understanding on the part of marketers. Although Ivory soap was an important brand for Proctor and Gamble ${ }^{9}$, it has not achieved the same distinctive role for $\mathrm{P} \& \mathrm{G}$ corporate identity as Sunlight achieved for Unilever. In his 1991 work Aaker prioritises successful P\&G brands to illustrate his advances in theory and then uses examples of problematic Unilever brands (Elizabeth Taylor's Passion perfume, and Lux Beauty Bar) to show poor examples of marketing decisions. Nonetheless, Aaker's views continued to be one of the dominant shapers of current branding theories.

\footnotetext{
${ }^{9}$ Ivory was trademarked in 1879 . Harley Proctor, son of the founder, was then responsible for converting the trademark into the brand. He did this by combining consumer insight, product knowledge, lab research and advertising. 0n $21^{\text {st }}$ December 1882 the first ad for Ivory appeared. It was unusual at the time to directly target consumers whereas most existing ads focussed on dealers and retailers.
} 
Kevin Keller (1993) extended Aaker's (1991) work and concentrated on brand knowledge as the core component of 'Customer-Based Brand Equity' (CBBE) which he defined as "the differential effect of brand knowledge on consumer response to the marketing of the brand." (1993: 8) Marketing efforts are thought to generate positive CBBE if consumers eventually respond to a given brand more favourably than to a made-up or unnamed version of the same product (or service). To put it another way, "[...] the power of a brand lies in what resides in the minds of customers." (Keller, 2003: 59) so marketing activities should always aim to develop all those desirable views that make customers like and, in the end, get close to a brand. Keller expressed his theory in the form of a pyramid which builds from the bottom on a foundation of Brand Salience (deep, broad awareness) to the peak of Brand Resonance (intense, active loyalty).

Twentieth century marketing theory has contributed to understanding the dyadic relational role that marketing plays in establishing relationships between producers and consumers. As noted above, scholars who have explored the development of marketing activities in the $19^{\text {th }}$ century have hypothesized an unidirectional transfer of meaning between producers and consumers through advertising. By using insights from contemporary brand theory we observe that Lever understood a reciprocal flow of meaning in terms of the development of the brand loyalty.

"It is said that the Sun never sets upon the British Empire. Sunlight (Soap) is also to be found in every part of the Empire"10

Aaker's choice of the P\&G brand Ivory as the centre-piece of his argument carries on a North American prejudice regarding lack of achievements of British firms operating in US territory. In 1888, Lever visited North America and established sales agencies in New York and

\footnotetext{
${ }^{10}$ Sunlight Soap advertising in 1894: UARM Maws Box 99+100.
} 
Montreal (Smith, 2014). He visited the US and Canada regularly to monitor progress of the companies he controlled but was shocked to find that:

“(I)n 1914 Lever Brothers’ turnover in Canada and the United States was £997,216 and $£ 187,923$, respectively. The fact that Lever Brothers sold more product in Canada than in the vastly more populous United States is striking: as the populations of the two countries were 7.2 million and 92.2 million, it appears that the per capita sales figures were 68 times higher in Canada than in the United States.” (Smith, 2014:142)

Smith argues that the explanation for the initial success in Canada is complex. He agrees with the factors identified elsewhere by business historians (differences in Tariffs, stronger trademark protection in Canada) but argues also that 'identity economics' plays a strong role and that the greater success enjoyed by Lever Brothers in Canada was, in part, rooted in Canada's strongly British identity. As we have argued, brands have value to customers through various means: the quality of the products and also through the identity which customers attribute to the brand. Lever learned a useful lesson from comparing the state of the Canadian subsidiary with the US counterpart. The totality of customer knowledge about the brand influences its success, and part of that knowledge is built through attaching significant associations to the brand. In the case of an unpopular association (Britishness) the brand must also find ways to diminish its importance by accentuating other brand associations.

When Lever introduced his soap in 1884, it joined competition with existing soap makers. By then, soap had changed from a luxury to becoming a necessity. This coincidence of need and affordability was seized on by Lever with the creation of his branded specialty "Sunlight Soap.” Through this entrepreneurial act Lever upset the existing competitive balance. In the view of one of his competitors, Christr. Thomas, of Bristol: 
"(T)here is little or no difference in quality between different makes of Bar Soaps there is a Thomas's Primrose, a Knight's Primrose and a Cook's Primrose - all the same soap. It is impossible, therefore by the nature of the case to ... (attempt) through advertising to create a demand in favour of any one particular make." (Wilson 1954:41).

Lever's competitors at that stage could not conceive a brand building considering soap was commodity product differentiated only by the makers' name. By 1884 Lever had outgrown his wholesale grocery business and was looking for a suitable trade-mark for a new soap of distinctive quality which he was developing in conjunction with an experienced soap chemist. He approached W. P. Thompson a Liverpool based patent agent, who offered Lever a number of names which they believed would be upheld in law if imitators tried to copy the product. After some consideration, Lever says the idea to adopt Sunlight as the name for his soap 'flashed across him' (Wilson, 1954:27).

Insert Figure 1 about here

The success of the name Sunlight was never guaranteed but Lever recognised early on the potential of an abstract trademark to be interpreted and assigned meaning by different stakeholders. The use of a common English term 'Sunlight' in a new context, as a name for soap acts as an 'identifier' of the commodity product. At the same time, it avoids using the manufacturer's name, which is not protectable.

Lever was one of the first English entrepreneurs to realise the importance of brand identity as a means of persuading customers. When he began work in his father's grocery business, 
laundry soap was made from tallow and was sold by weight, as a commodity. By means of an innovative chemical process Lever began making soap using vegetable fats. Whenever customers came looking for soap, the contrast between soap sold as commodity and Sunlight soap was made visible.

Insert Figure 2 about here

The first requirement of branding is the creation of a named identity which differentiates that good from all others in its category. Identity stands opposed to commodity. When Lever started to produce a new type of laundry soap, which contains copra or pine kernel oil and which helps it lather more easily than traditional laundry soaps made of animal fats he decided to make the bars of laundry soap available individually wrapped and in a box. He advertised the purity of his product and gave it a money back guarantee. (Fig. 2 above).

Marketing also includes innovation at the product level and not merely at advertising and promotion levels. Hence, in contrast to Church and Clark (2001), who seem to dismiss technological innovation underpinning success of soaps, we argue that the chemical product innovation introduced by Lever is in fact one component of the marketing mix - to develop a good brand, which is what contemporary marketing theorists recognised much later in $20^{\text {th }}$ century.

The idea of positioning is a modern marketing concept. Lever, however, was very explicit in stating who his soap is for. Lever coined the tagline "Less Labour, Greater Comfort", to position the brand directly at working class women. Less Labour for women, because the product lathers more easily. And greater comfort for all users, as the new chemical 
formulation was less abrasive or harmful to the skin than soaps made from tallow. The success of Sunlight was immediate. Within two years of the product launch, in 1887 Lever \& Co was making 450 tons of Sunlight soap a week, and William Lever bought the site to build Port Sunlight - a large factory on the banks of the Mersey opposite Liverpool. The purposebuilt village for its workers provided a high standard of housing and amenities (schools, library and leisure facilities). In the process, the registered name Sunlight, becomes a valuable piece of intellectual property, which has an analogue in the factory and the model town he created.

How does Sunlight anticipate the primary categories of brand equity?

Insert Table 1 about here

Sunlight Brand Awareness. Lever based his choice of the Sunlight name on a number of factors; it should be easy to remember and it was available to register as a trademark. Having chosen a suitable name, Lever then created a vigorous communications campaign of advertising and promotion to create a pull factor on the part of consumers ${ }^{11}$. No retailer could afford to ignore the demands of customers. With this strategy Lever was following trends he had observed in the US. "In 1888 (while his new factory at Port Sunlight was still under construction) the founder of Lever Brothers...visited America to arrange for a sales agency to handle his exports." (Wilkins, 1989:340) Lever made subsequent visits to America in 1893, 95, 96, and 98 .

${ }^{11}$ Wilson reports that Lever spent a mere $£ 50$ on advertising in the first year and during the next twenty years, advertising cost him $£ 2$ million pounds (p.43). 
Brand equity theorists all agree that name awareness is the necessary precondition for customers to become familiar with a brand. Sunlight Soap was advertised heavily in newspapers and magazines, outdoor campaigns including signage in the new railway stations, posters, advertisements in street cars, window displays, even on the back of postal stamps ${ }^{12}$, distribution of samples and use of premiums (prices and competition). He primarily targeted working class housewives and convinced them that soap "was not a luxury or a seminecessity, but an indispensable necessity for her home" (Wilson, p. 38). He used salesmen both to demonstrate his products and distribute samples as well as to gather information on what customers were thinking (Kelley, 2010) and he used these insights to position the new brand in relation to its competitors. In addition to creating name awareness among his target audience, Lever also produced a booklet 'Sunlight Soap and How to use it'. By doing this he goes further than simply engaging in brand awareness and instead contributes to consumer education and involvement. This was particularly useful for the emerging demographic segment of soap users nationwide.

\section{Sunlight Brand Loyalty.}

Records from the Soap Brand Register in the US (Berriman, 1905) show that there were more than 400 registered soap names including similar sounding to names to Sunlight such as Sunbeam, Sunburst, Sunflower, Sunrise, Sunshine and Sunset. One of the reasons underpinning success of Sunlight was the brand loyalty Lever created for the brand from the outset. He wrote in a letter to Sidney Gross, "we cannot separate success of Sunlight Soap from the means adopted to introduce it, we only know this that the Sunlight Soap in England

\footnotetext{
${ }^{12}$ New Zealand postage stamps 1893 with Sunlight Soap advertisements printed on the back: 'Sunlight soap is unequalled for hounds. Sunlight soap saves golden hours. Sunlight soap for washing dogs and prize poultry.' UARM Sunlight Soap advertising Maws Box 99 + 100 . (The only other instance of a soap being advertised on the back of a postage stamp was for Pears Soap in Great Britain in 1881. Source: The Unilever House Magazine, May 1949, p.25)
} 
is the most successful laundry soap introduced in any part of the world....and it is a fact that we have given prizes." ${ }^{\prime 13}$ (

Lever decided to use wrapper to address the problem of soap sweating (Church and Clark, 2001). He embossed the name Sunlight on the soap bar and wrapped it with the wrapper, which carried the name Sunlight. The wrappers were used as the basis for prizes for almost everything, from books to bicycles, which could be redeemed as a reward for collecting the wrappers $^{14}$. These individually wrapped bars of Sunlight initiated a new way for brands to capture the loyalty of customers.

Marketing theory teaches us that loyalty has two components, first is a behavioural disposition for repeat purchase and second is an attitudinal point of view wherein the consumer has a favourable psychological disposition towards the brand (Kotler and Keller 2015). Loyalty comes in different degrees of strength and Lever understood that prizes were a means of developing a stronger degree of loyalty, particularly to his customers from working class background. As a businessman, he also built in the cost of the prizes to the retail price of the soap. And lastly, the loyalty which the brand engendered made it imperative for retailers to keep it in stock. Once you have created loyal customers then the marketing costs and trade incentives can potentially be reduced.

Lever was acutely aware that sales promotion, particularly from the outset contributes in developing brand equity. This view is in contrast to the generally held view within the contemporary marketing community which considers sales promotions to dilute brand equity. Interestingly Lever also arrived at the same conclusion when sales of Sunlight soap declined

${ }^{13}$ UARM LBC 40/41: Lever's letter to Gross $7^{\text {th }}$ April 1903

14 'The awards are monthly, and there are no less than 232,000 prizes of bicycles, watches, books, and such like articles to the astounding value of $£ 41,904$ '. Sunlight Soap Competition, Bow Bells, 22 December 1893, 621. 
when he withdrew the prize scheme and competitors introduced their prize schemes. He acknowledged this in his correspondence with Gross, "I have had now seventeen years' experience with prizes for wrappers, and I can best illustrate my view on the subject by likening it to dram drinking. It appears to be most efficacious at first, but loses it affect after a time." 15 . In his reply to Lever's letter, Gross reminded Lever that wrappers for prizes did not happen in United States, and Lever need not go back to the prize scheme to increase the sales of Sunlight. ${ }^{16}$

Sunlight Perceived Quality. As mentioned previously, Sunlight Soap, represented both a product innovation and package innovation in the UK. The use of wrappers was to protect the outer box from the sweat of soap bars. Lever used the packaging to carry a message. He explicitly offered a guaranteed 'perfectly pure and genuine' quality of Sunlight, with $£ 1000$ reward offered to anyone who could prove existence of any 'harmful adulterant' in the soap. Seen through the marketing lens, perception of quality is a very critical contributor to brand equity (Aaker, 1991). By offering a reward of $£ 1000$, which incidentally was printed on every box of Soap (see Figure 2), he was developing perception of quality in his target audience for his brand. The function of the guarantee printed on the box was to make a promise of superior quality. Giving a guarantee for a huge sum of money helped to build trust with consumers. Perceived quality can be defined as “the customer's perception of the overall quality or superiority of product.....relative to alternatives" (Aaker, 1991; p.85). Perceived quality is an intangible, overall feeling about a brand. Lever understood the intangible dimension of perceived quality. His correspondence with Gross sheds light on this. He writes, "It seems to me that it entirely depends upon the connection between the Trade Mark and the article, and

${ }^{15}$ UARM LBC 40 - 41: Lever's letter to Gross $7^{\text {th }}$ April, 1903.

${ }^{16}$ UARM LBC 40-41: Sydney Gross letter to Lever $23^{\text {rd }}$ April, 1903. 
the attachment made to it... the figure can only be of value in driving home the trade mark. If it does not drive home the trade mark it is useless as an advertising idea.”. Lever cites, Lifebuoy, Monkey Brand, Quaker Oats and Oxo as trade marks which have clear figures attached. The figure is what drives the advertising. The special case of Sunlight was that it did not have any simple figure for direct visual association, instead Lever argues for a character and style of advertising which reinforces, "logical argument of quality"17

\section{Sunlight Brand Associations.}

Brand association, according to Aaker (1991:171), is "anything that is linked in memory to a brand". The strongest brand associations, "are those that can involve the customer to the point of becoming interwoven with his or her life". Lever attached the tagline -'greater comfort, less labour' to the Sunlight brand to overcome the negative association of the task of laundry which includes boiling, washing and scrubbing, performed by working class housewives. In addition he attached the tagline, "self-washer" as a positive association indicating that the task of laundry becomes easy with the use of his branded soap. Seen through contemporary brand theory perspective, these capture his effort to combine emotional (comfort) and functional (labour) attributes.

Port Sunlight, from very early on was described as 'workers' utopia' ${ }^{18}$ In much of the early advertising of Sunlight Soap, references were made to Port Sunlight where it was produced. Visitors to the factory had special access to watch manufacturing of soap. In this context, it is

${ }^{17}$ UARM LBC 4S - 46: Lever's letter to Gross, $26^{\text {th }}$ April 1907.

${ }^{18}$ Illustrated London News, $18^{\text {th }}$ March 1905: p.383. 
critical to highlight that Lever understood the value of public relation as delivering a message and a method of obtaining free advertising.

"The weather on Saturday, 28, November was wretched. In fact, as Mr Gladstone himself playfully observed... all the available sunlight of the day seemed to have been absorbed by the product manufactured by Messrs. Lever" ${ }^{19}$ This newspaper coverage of Gladstone's famous visit to Port Sunlight, illustrates the brand association between the Sunlight soap and Port Sunlight.

He also attempted to attach the brand to the Empire, for example by advertising an image of Britannia holding a bar of Sunlight soap. This reflects his attempt to position the brand as a solution to the universal problem of dirt and cleanliness and thus attaches the brand to wider imperialistic ideas.

\section{Conclusion}

We began by noting that 'brands' have attracted the interest of business historians, who have particularly focused on issues relating to trademark, economic value and legal protection. In contrast, debates on 'brands' in the marketing literature have only recently began with work of Aaker, Keller and others in 1990s. Their key focus is 'consumer based brand equity.' Current marketing research on brands and branding has overlooked the importance of the economic and social context of the history of brands, for example the development of trademark law in the $19^{\text {th }}$ century. In this case study of Sunlight Soap, we have attempted to bring the two strands of research (business historian and current marketing theory) together. In the process of critically examining the origin of the Sunlight brand by using contemporary

${ }^{19}$ George Sala, Illustrated London News, $5^{\text {th }}$ December 1891: p. 723. 
brand management principles, we demonstrate how trademarks evolve into consumer brands. Brand associations are enduring. Sunlight Soap is intrinsically linked to Port Sunlight, which originally was a business, social and philanthropic experiment. These origins of Lever's business idea underpin the ethos of Project Sunlight, the corporate social responsibility endeavour of Unilever Plc in 2010.

The long-term brand value in the case of Sunlight Soap, was not simply restricted to the market place, it also remained in the collective memory of the organisation. When Lever chose 'Sunlight' as the name for his new soap, he was giving voice to an instinct to bring together in one word a group of meanings: "to make cleanliness commonplace; to lessen work for women; to foster health and contribute to personal attractiveness, that life may be more enjoyable and rewarding for the people who use our products.” (Wilson, 1954). Financial brand value, even though in some cases is put on the balance sheet by some companies, is not unequivocal. In fact these values are contested. As Church (1999) pointed out, branding and marketing belong to that hinterland that lies between the realities of production and the facts of consumption. In this paper, we have defined brand equity as a bridge between those two domains. Bridge building is a slow process that requires all the elements of branding - brand awareness, brand loyalty, perceptions of quality and brand associations. Conversely, once brand equity is created it will also be slow to decline. 


\section{REFERENCES}

Aaker, D. 1991. Managing Brand Equity. New York: Free Press.

Baker, M. \& Hart, S. 1987. The Marketing Book. Oxford: Butterworth-Heinmann.

Baren, M. 1992. How It All Began. Yorkshire: Smith Settle.

Bently, L. 2008. The Making of Modern Trademark Law: The Construction of the Legal Concept of Trademark (1860-1880). In L.Bentley, J.Davis, and J.C. Ginsberg (Eds.), Trade Marks and Brands: An Interdisciplinary Critique: 3 -41. Cambridge: Cambridge University Press.

Berriman, C.S. (Ed.). 1905. The Soap Brand Register. New York.

Christodoulides, G. \& de Chernatony, L. 2010. Consumer-based Brand Equity Conceptualization and Measurement: A Literature Review. International Journal of Research in Marketing, 52(1): 43-66.

Church, R. 1999. New Perspectives on the History of Products, Firms, Marketing, and Consumers in Britain and the United States since the Mid-Nineteenth Century. The Economic History Review, New Series, 52(3): 405-435.

Church, R. 2000. Advertising Consumer Goods in Nineteenth - Century Britain: Representations. The Economic History Review, New Series, 53(1): 621-645.

Church, R. \& Clark, C. 2001. Product Development of Branded, Packaged Household Goods in Britain, 1870-1914: Colman's Reckitt's and Lever Brothers. Enterprise \& Society, 2(3): 503-541.

Church, R. 2008. Salesmen and the Transformation of Selling in Britain and the US in the Nineteenth and Early Twentieth Centuries. The Economic History Review, New Series, 61(3): 695-725.

Clark, P., \& Rowlinson, M.. 2004. The Treatment of History in Organisation Studies: Towards an 'Historic Turn'?" Business History, 46(3): 331-352.

Cobb-Walgren, C., Ruble, C. \& Donthu, N.. (1995). Brand Equity, Brand Preference, and Purchase Intent. Journal of Advertising, 24(3): 25-40.

da Silva Lopes, T. 2003. The Growth and Survival of Multinationals in the Global Alcoholic Beverages Industry. Enterprise \& Society, 4(4): 592-598.

da Silva, Lopes.T., \& Casson, M. 2007. Entrepreneurship and the Development of Global Brands. Business History Review, 81: 651-680.

da Silva, Lopes,T. \& Duguid, P. 2010. Brands and Competitiveness." In T. da Silva Lopes \& P. Duguid (Eds.), Trademarks, Brand and Competitiveness: 1-8. Abingdon: Routledge. 
Decker, S., M. Kipping., \& Wadhwani, R.D. 2015. New Business Histories! Plurality in Business History Research Methods. Business History, 57(1): 30-40.

Dugid, P. 2003. Developing the Brand: The Case of Alcohol, 1800-1880. Enterprise $\&$ Society, 4(3): 405-441.

Fullerton, R. A. 1988. How Modern Is Modern Marketing? Marketing's Evolution and the Myth of the "Production Era". Journal of Marketing 52(1): 108-25.

Levy, S., \& Gardner, B. 1955. The Product and the Brand. Harvard Business Review 33(2): 33-39.

Holbrook, M.B. 1992. Product Quality, Attributes, and Brand Name as Determinants of Price. Marketing Letters 3(1): 71-83.

Hutchinson, R. 2003. The Soap Man, Lewis Harris and Lord Leverhulme. Edinburgh: Birlinn.

Ignatius, A. 2012. Captain Planet: Interview with Paul Polman. Harvard Business Review, June: $112-118$.

Jones, G. 2005. Renewing Unilever: Transformation and Tradition. Oxford: Oxford University Press.

Jolly, W.P. 1976. Lord Leverhulme: A Biography. London: Constable.

Kapferer, N. 1992. Strategic Brand Management. New York: Free Press.

Keller, K. 1993. Strategic Brand Management. London: Pearson.

Kelly, V. 2010. Soap and Water: Cleanliness, Dirt, and the Working Class in Victorian and Edwardian Britain. London: I.B. Tauris.

Kieser, A. 1994. Why Organization Theory Needs Historical Analyses - And How This Should Be Performed. Organization Science, 5(4): 608-620.

Knox, A.M. 1976. Coming Clean: A Postscript after Retirement from Unilever. London: Heinemann.

Kornberg, M. 2010. Brand Society: How Brands Transform Management and Lifestyle. Cambridge: Cambridge University Press.

Kotler, P., \& Keller, K.L. 2015. Marketing Management. Pearson.

Levy, S., \& Rooks, D. 1999. Brands, Consumers, Symbols and Research. Sage.

Lewis, B. 2008. So Clean: Lord Leverhulme, Soap and Civilization. Manchester: Manchester University Press. 
Lewis, B. 2014. "To Lever's on Soap!” Roger Casement, Slavery, and Sexual Imperialism." In Gwyn Campbell and Elizabeth Elbourne (Eds.), Sex, Power and Slavery. Ohio University Press.

Lury, C. 2004. Brands: The Logo of the Global Economy. New York: Routledge.

Lury, C. 2008. Trade mark style as a way of fixing things. In L. Bentley, J. Davis, \& J. C. Ginsberg (Eds.), Trade Marks and Brands: An Interdisciplinary Critique: 201-223. Cambridge: Cambridge University Press.

Macqueen, A. 2011. The King of Sunlight: How William Lever Cleaned Up the World. Corgi.

Marchand, R. 1985. Advertising the Marketing Dream: Making Way for Modernity, 19201940. Berkley: University of California Press.

Mercer, J. 2010. A Mark of Distinction: Branding and Trade Mark Law in the UK from the 1860s. Business History, 52(1): 17-42.

Miskell, P. 2013. Unilever's (Other) Brand Wars. In T. da Silva Lopes \& P. Duguid (Eds.), Trademarks, Brand and Competitiveness: 215-234. Abingdon: Routledge.

Pope, D. 1991. Advertising as a Consumer Issue. Journal of Social Issues 47(1): 41-56.

Richard, T. 1991. The Commodity Culture of Victorian England-Advertising and Spectacle 1851-1914. London: Verso.

Rowan, J.D. 2003. Imagining Corporate Cultures: The Industrial Paternalism of William Hesketh Lever at Port Sunlight, 1888-1925. Unpublished doctoral dissertation, Louisiana State University.

Rowlinson, M., \& Hassard, J. 1993. The Invention of Corporate Culture: A History of Histories of Cadbury. Human Relations 46(3): 299-326.

Ries, A., and J. Trout. 1972. Positioning: The Battle for Your Mind. McGraw - Hill Education.

Rust, R. T., Zeithaml, V.\& Lemon, K. 2000. Driving Customer Equity. New York: The Free Press.

Saiz, P., \& Castro, R. 2015. The Brand and its History: Economic, Business and Social Value. Business History.

Schroeder, J. E., \& Salzer-Morling, M. (Eds.). 2006. Brand Culture. London: Routledge.

Schwarzkopf, S. 2013. Turning Trademarks into Brands: How Advertising Agencies Practiced and Conceptualized Branding, 1890-1930. In T. da Silva Lopes \& P. Duguid (Eds.), Trademarks, Brand and Competitiveness: 165-193. Abingdon: Routledge. 
Sharp, B. S. 1995. Brand Equity and Market Based Assets of Professional Service Firms. Journal of Professional Services Marketing 13(1): 3-13.

Smith, A.D.A. 2014. A Successful British MNE in the Backyard of American Big Business: Explaining the Performance of the American and Canadian Subsidiaries of Lever Brothers 1888-1914. Business History 56(2): 135-160.

Smith, T. 1992. Accounting for Growth. London: Random House.

Stephen, A. 1991. Selling Soap: Domestic work and consumerism. Labour History 61: 57 69.

Strasser, S. 1995. Satisfaction Guaranteed: The Making of the American Mass Market. Washington DC: Smithsonian.

Tedlow, R. S. 1990. New and Improved: The Story of Mass Marketing in America. UK: Heinemann.

Usdiken, B., \& Kieser, A.. 2004. Introduction: History in Organisation Studies. Business History 46(3): 321-330.

Wadhwani, D.R., \& Bucheli, M.. 2013. The Future of the Past in Management and Organizational Studies. In M. Bucheli and R.D.Wadhwani (Eds.), Organizations in Time: History, Theory, and Methods: 3-13. Oxford: Oxford University Press.

Wilkins, M. 1989. The History of Foreign Investment in the United States: $1914-1945$. Cambridge, MA: Harvard University Press.

Wilkins, M. 1991. The Neglected Intangible Asset: The Influence of the Trade Mark on the Rise of the Modern Corporation. Business History 34(1): 66-95.

Williams, H. 1948. Men of stress: Three dynamic interpretations; Woodrow Wilson, Andrew Carnegie, and William Hesketh Lever. London: Jonathan Cape.

Wilson, C. 1954. The History of Unilever: A Study in Economic Growth and Social Change. 2 vols. London: Cassell \& Co.

Wilson, C. 1968. The History of Unilever: A Study in Economic Growth and Social Change. vol. 3 1945-65. London: Cassell \& Co.

Wilson, J, \& Toms, S. 2008. 50 Years of Business History. Business History 50(2): 125126. 


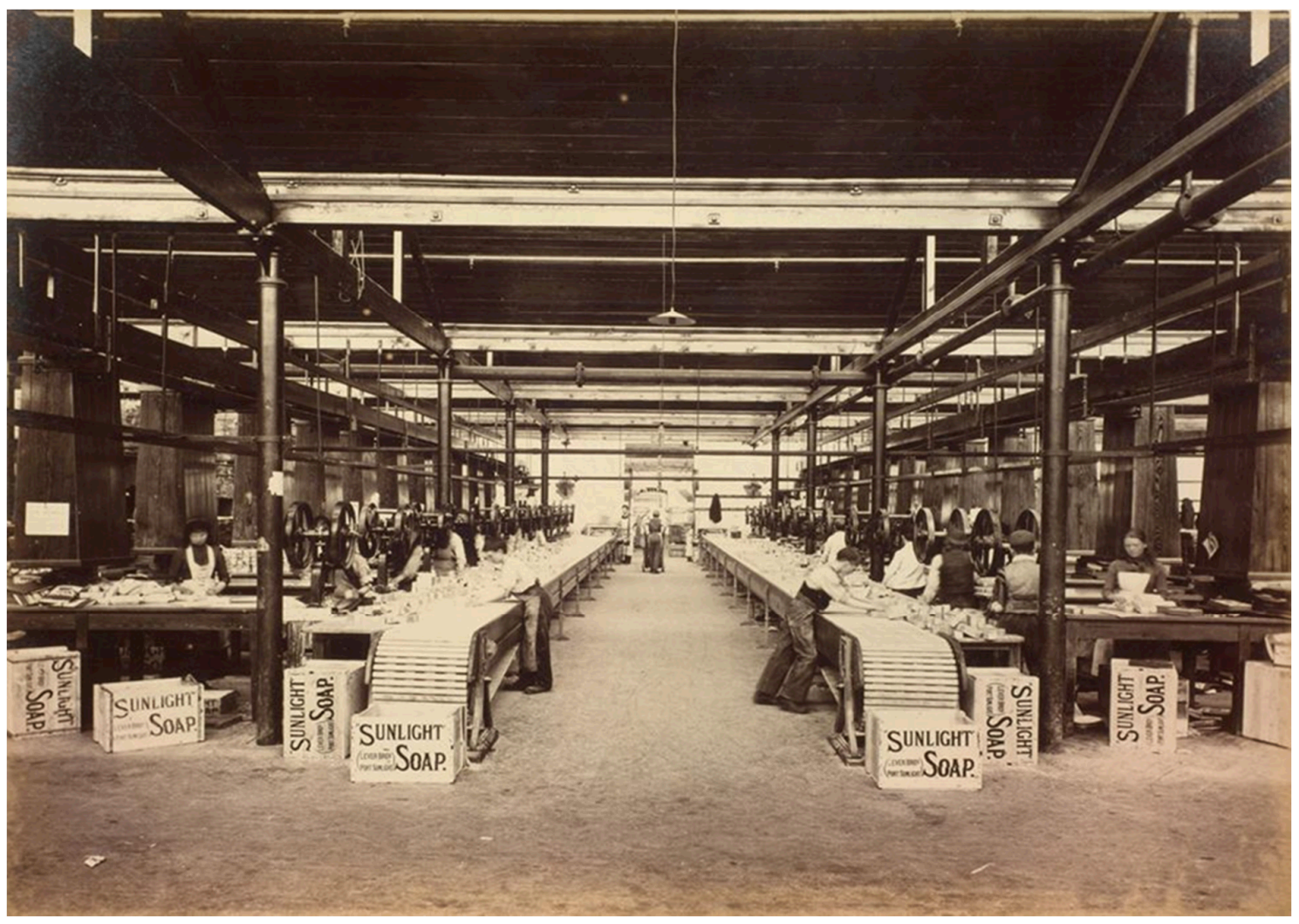

Fig 1. The first brand to emerge from the darkness of commodities. 


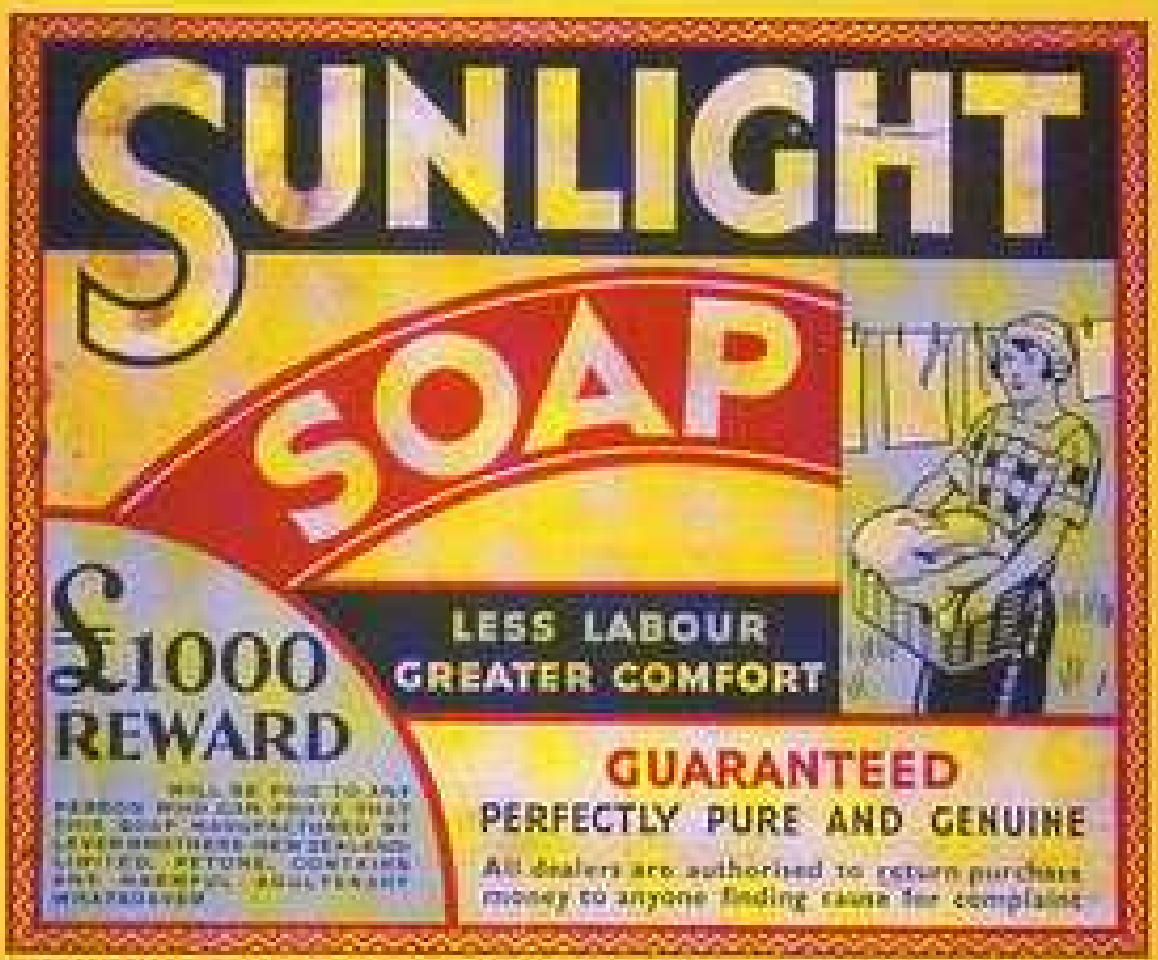

Fig 2. Sunlight Soap packaging. 


\begin{tabular}{|c|c|c|}
\hline $\begin{array}{l}\text { Dimensions of } \\
\text { Brand Equity }\end{array}$ & Sunlight Soap & Rationale \\
\hline Brand Awareness & $\begin{array}{l}\text { Unique, memorable, legally } \\
\text { protectable, name. Worldwide } \\
\text { trademark protection. }^{20} \\
\text { Systematic use of intensive } \\
\text { advertising to create name } \\
\text { recognition; }{ }^{21}\end{array}$ & $\begin{array}{l}\text { Brand to be considered, sign of } \\
\text { familiarity, liking }\end{array}$ \\
\hline Brand Loyalty & $\begin{array}{l}\text { Individually wrapped (in faux } \\
\text { parchment) bars of soap bearing } \\
\text { the brand name. Competitions, } \\
\text { collecting wrappers. Market } \\
\text { research on customer preferences } \\
\text { and habits. }{ }^{22}\end{array}$ & $\begin{array}{l}\text { Trade leverage, reduced } \\
\text { marketing costs }\end{array}$ \\
\hline Perceived Quality & $\begin{array}{l}\text { Guarantee of purity, with cash } \\
\text { reward; affordable necessity for } \\
\text { the working classes. }\end{array}$ & $\begin{array}{l}\text { Reason to buy, position and } \\
\text { differentiation. Price }\end{array}$ \\
\hline
\end{tabular}

${ }^{20}$ Sunlight was registered in the UK in 1884 , in India and Spain by 1888 , and the US and Australia by 1895.

21 See Wilson (1954) and Stephen (1991) p.59-60. In this context it is important to note that Lever \& Co. founded their own advertising agency, Lintas, in 1899.

${ }^{22}$ Wilson notes that Lever collected information from his sales people about their conversations with customer. Today such a practice is called focus group. Lever is also credited with first ever product placement of Sunlight Soap in moving pictures. In May 1896, in the yard of the Geneva home of Lavanchy-Clarke (a Swiss businessman who functioned as a European distributor and promoter for the U.K. soap manufacturer Lever Brothers), the cinematographe operator Alexandre Promio (Lumiere Brothers) shot a film of two women hand-washing tubs of laundry. Placed prominently in front of the tubs were two cases of Lever Brothers soap, one with the French branding "Sunlight Savon," the other with the German "Sunlight Seife." The following month, the film ("Laveuses"), given the English title "Washing Day in Switzerland (Promio, 1896)", was shown in New York at Keith's Union Square Theatre (1896). The official release date is 26 September 1896. 


\begin{tabular}{|l|l|l|}
\hline Brand Associations & Concern for all stakeholders & Help to process and retrieve \\
& $\begin{array}{l}\text { (investors, workers, customers); } \\
\text { The Workers Utopia of Port } \\
\text { Sunlight }\end{array}$ & information \\
\hline \multicolumn{2}{|l}{} \\
Table 1. Aaker's brand equity categories applied to Sunlight Soap \\
\hline
\end{tabular}

